\title{
Encountering the Past: Grand Narratives, Fragmented Histories and LGBTI Rights 'Progress'
}

\author{
Kay Lalor ${ }^{1}$ iD
}

Published online: 29 March 2018

(C) The Author(s) 2018

\begin{abstract}
Past and future coalesce in discussions of LGBTI rights, often embedded in narratives of progress, civilisation, colonisation and emancipation. An understanding of these dynamics can help to illuminate the complex power relations that currently striate international LGBTI rights discourses. This paper analyses how temporality operates in the context of international LGBTI rights through an examination of the World Bank's withdrawal of a $\$ 90$ million loan to Uganda after the passage of the Anti-Homosexuality Act 2014. To do this, the paper juxtaposes postcolonial critiques of the ongoing international legal reproduction of the colonial encounter, with a Deleuzian conception of law's 'virtual memory'. These two theoretical lenses are used to show how attempts to advance LGBTI rights can reproduce problematic civilisational binaries, through which the Global North seeks to manage the unruly or 'uncivilized' Global South. These civilisational and spatial dichotomies are often obscured by un-interrogated 'grand narratives' of progress and by the codification of specific, narrow forms of rights protections. As such, the paper argues that in order to better advance current and future frameworks for sexual orientation and gender identity justice, we must undertake a more attentive encounter with the past.
\end{abstract}

Keywords Anghie - Anti-Homosexuality Act · Deleuze · LGBTI rights · Uganda · World Bank

Kay Lalor

k.lalor@mmu.ac.uk

1 Manchester Law School, Manchester Metropolitan University, Lower Ormond St, Manchester M15 6BH, UK 


\section{Introduction}

This paper explores the operation of time and temporality in the pursuit of international LGBTI (lesbian, gay, bisexual, transgender and intersex) rights. ${ }^{1}$ It is concerned with the temporal legal mechanisms that reduce arguments around SOGI (sexual orientation and gender identity) justice to a restrictive dichotomy of 'LGBTI rights as progress'/'LGBTI rights as neo-imperialism'. This framing ensures that gender and sexuality are symbolically integrated into (repetitive, inaccurate and restrictive) logics of civilisational clash. It devolves upon broad and inexact spatial demarcations of Global North/Global South, and reflects colonial binaries of developed/developing or civilised/uncivilised worlds. Given these limitations, I argue that there is an urgent need to imagine new and experimental frameworks of action for SOGI justice.

This argument is advanced through an examination of a recent, high profile and complex event in LGBTI rights - the withdrawal of a \$90 million World Bank loan from Uganda following the passage of the 2014 Anti-Homosexuality Act (AHA). This case is deliberately chosen for the complexity of the dynamics that it assembles. The loan's cancellation was a direct response to a hugely regressive piece of domestic legislation; it followed a trend of increasing international and transnational support for LGBTI rights. In withdrawing the loan the Bank claimed greater influence over issues of sexuality and gender, and expanded the role of legal or quasilegal institutions in the development of international legal norms of SOGI in a way that led to a much stronger international focus on the economic costs of homophobia and economic approaches to LGBTI discrimination. Yet even this somewhat experimental or expansive approach to LGBTI rights maintained structural, conceptual and spatial dynamics of Western 'management' of the unruly or uncivilised 'developing world'. These dichotomies were particularly problematic within Uganda, where the Bank's actions were integrated into a narrative of Western neo-imperial importing of homosexuality.

The perpetuation of dynamics of civilisational clash, even at this 'cutting edge' of LGBTI progress, demonstrates an urgent need for approaches to SOGI that undermine the civilised/uncivilised binary. This requires conceptual reworkings of dominant LGBTI rights trends as well as practical policy proposals. It is the former with which this paper is most concerned: I argue, with Anghie (2013), that 'we need a better framework to see how novelty develops'. To do this, I bring two sets of analytical lenses into the conversation. The first is TWAIL (Third World Approaches to International Law) - particularly Anghie's (2007) analysis of the civilised/ uncivilised binary that underpins the colonial encounter and animates present practice of international law. The second is Deleuzian jurisprudence and Lefebvre's 'habitual judgment'. These deliberately disjunctive lenses both foreground time and

\footnotetext{
1 In using 'LGBTI' and 'LGBTI rights' here, I am drawing on the terminology adopted by Ugandan and other activist groups when engaging with the World Bank and when documenting human rights abuses. However, other terms have been used in different contexts and as Rao (2014) notes, 'kuchu' has become the preferred identity description for many Ugandan LGBTI individuals.
} 
temporality, while also illuminating different weaknesses in current frameworks of LGBTI rights. TWAIL scholars have long identified the ongoing and pernicious effects of civilisational dynamics in international law as well as the need to identify new approaches that subvert these dynamics. Deleuze offers a critique of the dialectic and of law that helps to better enunciate a challenge to these long accepted binary positions.

The paper first draws upon TWAIL and Deleuzian literatures of law and time to explore how legal-temporal dynamics of 'habitual repetition' lead to the creation and repetition of legal 'grand narratives'. It then applies this theoretical framework to the context of the AHA and to the withdrawal of the World Bank loan. I then argue that the withdrawal of the loan is an example of Lefebvre's (2008) 'habitual repetition' of a civilised/uncivilised binary, and it is only through the (denied but activated) grand narratives of this binary that the Bank's actions can be fully understood. In the final sections of the paper, I return to Deleuzian literatures of law and time to explore ways in which this colonial repetition might be made visible and overcome, or how international law might be 'queered' in pursuit of new frameworks for SOGI justice.

\section{Grand Narratives and Repetitive Judgment in Human Rights Law}

The theoretical framework adopted in this paper centralises how history and memory exist in law. Most significant here is Anghie's (2007, p. 288) analysis of the way that historically situated structures of thought pertaining to the 'foreign' or the 'uncivilized' are repeatedly reproduced. In this section I draw upon the Deleuzian concept of virtual memory and Lefebvre's 'habitual repetition of law' as a framework for problematising for the legal operation of this civilisational dynamic.

For Deleuze, memory exists as a virtual whole and time is a multiplicity in which different times_-past, present and future — are dimensions of each other (Williams 2011 , p. 164). In this sense, the progression of time is not confined to a space-time continuum, instead past and present are 'but two elements which coexist: One is the present, which does not cease to pass, and the other is the past, which does not cease to be but through which all presents pass' (Deleuze 1991, p. 59). This multidimensional approach to time rests on the presupposition of a multiplicitous 'virtual memory' or 'past in general'. This past in general is a condition of the present, there is a 'virtual coexistence of the past in each moment of the present' (Grosz 2000, p. 225). Virtual memory is therefore multivocal: a polyphony.

As such, virtual memory is beyond consciousness or recollection: '[i]t is we who belong to memory, to different planes of the past' (Al-Saji 2004, p. 228). By its very nature, virtual memory may only be presupposed - it is known only through its actualisation in the present moment and this actualisation will depend upon the position from which virtual memory is approached. As such, 'The present makes an appeal according to the requirements or needs of the present situation' (Deleuze 1991, p. 62) and from this appeal we place ourselves at a particular level of the virtual past, at a particular level of tension. Actual present and virtual memory coexist according to the needs of the present, and the actualisation of virtual memory at a particular level allows for the rearrangement of the virtual elements actualised. 'The pure past 
is of the past, but amenable to change through the occurrence of any new present' (Williams 2003, p. 96). Memory will contract and rotate towards the situation at hand (Deleuze 1991, p. 64).

Just as a multiplicitous virtual memory is actualised at a particular level of tension according to the perception of a present moment, the virtual memory of law, or the 'pure past of law' (Lefebvre 2008, p. 147), is actualised as a singular and coherent legal narrative through the process of judgment. For Lefebvre, judgment is the act of perceiving a legal issue and using the specifics of this perception to actualise the virtual memory of law at a particular level of tension. This creates a clear and coherent legal argument:

Any case has an infinity of points and sides that go neglected, facts irrelevant to the interest at hand that exceed its eventual legal construction. Here, we can draw a distinction between a case as it is not yet represented, as it is a pure event or image in the world, and a legal case as it is pragmatically perceived, as it is reflected according to interests... The perception of a case...is limiting and subtractive; only certain crucial points are advanced and constructed into legal argument, but underlying these points is the case in itself, unperceived, or given to perception that part that interests the perceiving parties. (Lefebvre 2008, p. 123)

Significantly, Lefebvre suggests that, in general, the actualisation of the past goes unnoticed: we recognise what is familiar and select appropriate habits and recollections (Lefebvre 2008, pp. 67, 168). Thus an instant is perceived (inattentively) as a representation or reiteration of something that has already been encountered (a recollection). A stock of habit memories and judgments are taken as already existing and able to respond to the situation at hand. 'In this sense, the question or problem posed by the image is suppressed in favour of the recognition and activity supplied by a recollection' (Lefebvre 2008, p. 168). Law and time progress in a linear sense, along paths, patterns and divisions that are already known.

De Vos has explored the idea of progress along an accepted path in the context of the 'grand narrative' of movement from a dark apartheid past to a bright future in South Africa. He argues that this grand narrative animated South African judgments in the years following the fall of apartheid and adoption of the new South African Constitution. It was employed by judges as an 'objective' standard for their judgments, thereby avoiding questions of subjectivity, arbitrariness, politicisation or bias (de Vos 2001). However, the construction of a unified and relatively unproblematic grand narrative fosters a form of inattentive judgment. A grand narrative must necessarily privilege some views and voices over others and it tends to do so in relation to a vector of power, which guides perception of situations, representations and identities. These representations and identities become the 'habit-memories' through which judgment is advanced.

The operation of habitual judgment is both logical and necessary: it facilitates a predictable narrative that guides judgment. Yet even widely agreed-upon constitutional versions of history are always partial: '[H]istory is inevitably a product of the present and reflects our understanding of the present' (de Vos 2001, p. 20). This reflects what Greenhouse (1989, p. 1640) refers to as the 'mythic' dimension of law: 
the 'quality of being in time (in that it is a human product) but also out of time (where did it or does it begin or end?) and in its promise of systematic yet permutable meaning'. By drawing upon this mythic dimension, legal actors are able to frame their arguments as objective and rational-or more succinctly, law uses its own myth to deny the very subjectivity of that mythmaking process. Temporalities are absorbed and obscured by law as it 'expands and compresses time by emphasizing, erasing, and recasting historical events' (Mawani 2015, p. 261).

The legal manipulation of time operates internationally as well as domestically. For example, in keeping with Greenhouse's observation that law is both within time and timeless, Anghie (2007, p. 220) traces the way in which, during the postwar period, international lawyers simultaneously relied on the past-and upon the effects of colonialism - to insist upon concessions from new states, while simultaneously denying the reality of colonialism and colonial history. The universalisation of international law rested upon de-temporalisation-which manifested as an appeal to law as that which was always already in place (Anghie 2006). This reliance upon, and obfuscation of, the past continues into the present: the civilised/uncivilised binary becomes an important but unacknowledged grand narrative within international legal arenas. This binary animates the smooth operation of international law but, to maintain law's claim to universality and objectivity, its foundational status must be denied. In this way, particular forms of legal knowledge and legal action are presented as objective and legitimate — 'habitual' and unremarkable modes by which we understand and act within a particular situation or set of situations.

Lefebvre's analysis and de Vos' examples are concerned with adjudication rather than with entire frameworks of law. The development of this analysis into questions of international law and human rights is therefore an extension of Lefebvre's argument-into what he calls 'the institutions and protections of a global Deleuzian jurisprudence' (Lefebvre 2008, p. 87). This extension is itself grounded in Deleuze's comment that human rights are 'pure abstraction' that fail to account for a perceived situation (Deleuze 1996). In this respect, Lefebvre argues strongly against abstract standards of human rights that are detached from real world scenarios (Lefebvre 2008, p. 87). Drawing upon this argument, we can examine international legal action in support of LGBTI rights by tracing acts of perception of a set of legally relevant facts and the actualisation of the virtual memory of international law.

This extends an important analytical point with respect to the World Bank and the AHA. The World Bank has no legislative or judicial power, yet its actions were clearly intended to have a legal effect and to perpetuate a particular vision of protection of international LGBTI rights. To this end, Duval (2013, p. 836) argues that we should be 'agnostic' about sources of law, and 'aware of the available legal tactics to either confront or integrate a specific transnational source of law in another legal context'. In adopting this approach, it is possible to take a broad view of the complex multiplicity of factors that are perceived as legally relevant or irrelevant to a case or an issue. This was certainly the case in the wake of the AHA-a multiplicity of issues were perceived or misperceived as relevant in different legal and quasi-legal contexts. And with each perception and habitual repetition of virtual memory, wider systematic and normative processes were reinforced. This repetition in the international sphere is why agnosticism about the sources of law is necessary: a broadened 
view demonstrates how normative force is exerted, repeated and perpetuated through the acts of quasi-legal bodies like the World Bank, and how the colonial legal histories of these acts are obscured. The analysis below first examines the domestic Ugandan context and then the actions of the World Bank to show how SOGI, rights, history and empire were differently perceived in different legal settings, and the tensions that arose as a result of these conflicting temporal legal perceptions.

\section{Colonial Memory and the Ugandan Anti-Homosexuality Act 2014}

The section above makes three related claims. First that law is intimately linked to perception. To be represented as a case or a legal issue, an event must be perceived as such - and this act of perception involves acts of limitation, subtraction, or selection of relevant points. Second, this perception involves the manipulation of time and temporalities, including through the construction of 'grand narratives' that make perception habitual or unnoticed. Third, this temporal manipulation is exemplified in international law's denial of its colonial past and simultaneous reliance on the structures, institutions, legal systems and norms that were created through the colonial encounter. I argue below that these three factors-perception, temporality and the colonial encounter-were all present in Ugandan framings of the AHA.

Historically, the control of gender and sexuality has played a role in the colonial project-often integrated into the 'civilizing missions' of European states (McClintock 1995; Uberoi 1996). This is emphatically the case in Uganda where, in 1885, a group of newly converted Christian pages appear to have been executed after refusing same sex intimacy with Kabaka (king) Mwanga II. The executions played a central role in events that led to British colonial rule (Rao 2014). Within present Ugandan politics, the pages are often presented as martyrs who would rather die than 'submit' to sodomy (Rao 2014, p. 190). In this narrative, the potential of Mwanga as a symbol of colonial resistance is muted in favour of a form of memory that privileges the heterosexuality and Christianity of Ugandan history. The irony of this, of course, is that in Uganda, as with many other states, the current criminalisations of sodomy or 'unnatural offences' were first imposed by the British Empire (Gupta 2008).

From the introduction of the Anti-Homosexuality Bill (AHB) in 2009 to the passage of the AHA in 2014 and the battle for its repeal, Ugandan activists were keenly aware of the danger of portraying homosexuality as a 'western invention', in a way that validated anti-LGBTI stances as assertions of post-colonial sovereignty (Jjuuko 2016). The stated objectives of the AHB in the debates surrounding the bill make reference to 'internal and external threats to the traditional family', 'the cherished culture of the people of Uganda' and the vulnerability of children as a result of 'cultural change'. ${ }^{2}$ Thus, dominant grand narratives that mark homosexuality as

\footnotetext{
2 See the Hansard record of 20 December 2013 where these objectives are outlined at http://hansa rd.parliament.go.ug/cmis/browser/Sites/website-documents/documentLibrary/Hansards/Hansards_2013/ December2013. Accessed 27 November 2017.
} 
'foreign' and un-African, and render anti-homosexuality as compatible with antiimperialism were embedded in the text of the AHB. This narrative is limiting and limited: as Nyanzi (2014, p. 37) comments:

The bill was drafted by Ugandans, but its genesis and support are intricately interwoven with a complex assemblage of local, continental, and global foreign influences, including the homophobic rhetoric of some African presidents, powerful collaborations with conservative US evangelicals, and the diffuse discourses of some bishops of the Anglican churches.

Equally, this anti-colonial rhetoric masked a more complex and less monolithic political picture. Committee reports on the AHB demonstrate a variety of views, ranging from vocal support, to questions around the feasibility of implementation, to the argument that the state 'must not be allowed into the bedrooms of people' (Nyanzi and Karamagi 2015). Politically, as Nyanzi and Karamagi (2015, p. 35) argue, the AHA was about more that the regulation of sexuality; it was 'appropriated by politicians advancing their advantage within an undemocratic 39-yearold regime.' This appropriation included appeals to national sovereignty-which became synonymous with 'fighting homosexuality' (ibid., p. 33). It also encompassed the exploitation of anxiety around the destabilisation of family life, procreation and material exchange by elite actors (Sadgrove et al. 2012, p. 106), in which homosexuality came to represent the erosion of 'African values' by Western groups engaged in gay 'recruitment', often through economic incentives (ibid.). This anxiety was further complicated by religious norms in which many (although not all) Ugandan religious figures-sometimes with the support of powerful transnational evangelical movements_-preached against homosexuality (Kaoma 2012).

It is within this complex context that a petition was filed with the Ugandan Constitutional Court alleging the unconstitutionality of the passage of the AHB and the AHA's violation of a number of constitutionally protected rights. The judgmentOloka-Onyango and 9 Others v. Attorney General-is narrow. The Court annulled the AHA on the basis that Parliament had not been quorate when the AHB was passed. It declined the opportunity to consider wider issues of sexuality, discrimination and rights protection, instead framing - or perceiving - the case as one of procedure.

In its narrow framing, Oloka-Onyango has followed a pattern found in a number of other Ugandan sexuality rights cases, in which questions of morality, dignity and sexuality have been sidestepped. Jjuuko (2013) depicts this as an 'incremental' approach, which sought to build slowly on already existing rights protections in a form of habitual judgment that carefully side-lines questions of imperial or colonial histories as not legally relevant. For example, in David Kato Kisuule \& Onziema Patience v. Rolling Stone Ltd \& Giles Muhame, even while upholding the privacy rights of LGBT applicants, the judge stressed that the case 'was not about homosexuality per se' (Oloka-Onyango 2015, p. 38).

These legal strategies demonstrate how conceptions of time, temporality and memory play into anti-colonial rhetoric and how carefully activists must manage these dynamics in their legal strategies. The incremental approach adopted as part of this management has had some success. Below, I argue that the Bank's approach 
was much less careful in its approach to time, its perception of the issues at stake and its engagement with colonial histories.

\section{The World Bank and the Creation of the Economically Excluded LGBTI Subject}

Despite the efforts of Ugandan activists, colonial memory played an animating role in debates around the AHA. Although grand narratives of colonial encounter or civilisational clash were not explicitly named in the World Bank's actions, I argue that in linking the loan's withdrawal to the AHA, a great deal of temporal manipulation was required and a binary of civilised/uncivilised underpinned much of what occurred.

Following the passage of the AHA, diplomatic and other support flooded into Uganda (Jjuuko 2016). Several states cancelled or diverted foreign aid, but the figures involved were dwarfed by the withdrawal of the $\$ 90$ million loan, which had been intended to support a project to improve maternal healthcare (Wahab 2016, p. 710). A number of incongruities can be pointed out here. First, there is the question of the Bank's authority to act in relation to the AHA. Article IV, Section 10, of the Bank's Articles of Agreement states:

the Bank and its officers shall not interfere in the political affairs of any member; nor shall they be influenced in their decisions by the political character of [a] member.... only economic considerations shall be relevant to their decisions, and these... shall be weighed impartially in order to achieve the purposes stated in Article I.

This political prohibition has historically led to a lack of involvement on the part of the Bank with human rights (Darrow 2006; Fujita 2011). Despite some movement on this issue, a consistent policy on human rights is still generally lacking (Menashy 2013) and the Bank has itself been involved in projects which have led to human rights violations (Alston 2014; Brodnig 2002). Moreover, while the Bank has generally been willing to regulate 'normative arrangements of intimacy' (Bedford 2009, p. xii), the Bank's direct engagement with SOGI has, until recently, been relatively limited (de Camargo Jr. and Mattos 2007; Gosine 2010).

Second, there is the question of why a loan linked to maternal healthcare was withdrawn in the wake of LGBTI persecution. In a letter to the Bank's employees following the loan's initial delay, World Bank President Kim emphasised that 'These acts of discrimination against a group of people because of their sexual orientation cannot be tolerated...Institutionalized discrimination is bad for people and for societies. And as we know well in this institution, widespread discrimination is also bad for economies' (Feder 2014; Kim 2014). In a letter addressed to President Kim in response to the loan's delay, activists made a link with the need to ensure that 
healthcare services are non-discriminatory. ${ }^{3}$ But even with these perspectives, the connection between the AHA and maternal healthcare remains tangential.

Thus, for a body prohibited from political action, the Bank's cancellation of the loan seems to be a highly political act. A temporal analysis can offer some direction here. Historically, Anghie argues that international financial institutions (IFIs) maintain a trajectory of colonial management and utilise techniques of discipline and control very similar to those used under the mandate system (Anghie 2002). In this way, the Bank's actions can be said to maintain a civilisational dynamic in which the undifferentiated, 'homophobic' Global South must be pushed to 'progress'. However, even if we accept that the Bank can be schematised as part of an ongoing system of control, the Bank's foray into SOGI issues still requires a subversion of the political prohibition. The justification for this subversion is found within the Bank's turn to 'good governance' in the late 1990s. Through the promotion of good governance and the rule of law as vital to development, the Bank was able to broaden the scope of its activities into areas which would once have been considered political and thus outside of its competencies (Darrow 2006, p. 112; Anghie 2007). This then, is an issue of perception: by recasting issues as pertinent to good governance, the Bank (itself not a legal body) can claim ownership over an expanded range of issues-potentially including gender and sexuality. A similar shift allows for the linkage of human rights to good governance agendas. In 2006, the General Counsel of the World Bank argued that 'Acknowledging the relevance of human rights to the Bank and integrating human rights into its work is an important element in our efforts to step up the Bank's promotion of good governance and its global fight against corruption' (Palacio 2006). In this way, human rights, good governance and development become the foundation for the Bank's authority to intervene in a range of issues that would once have been considered highly 'political'.

This reorientation allowed for the regulation of intimate life by IFIs, and the promotion of particular family structures, policies and healthcare agendas as necessary to economic development and good governance. This was reinforced by a shift from the Bank's general blindness to issues of LGBTI rights to an increasing inclusion of SOGI in some discussions at the Bank (Gosine 2010). In 2014, for example, the Bank released a report that linked the exclusion of and discrimination against LGBTI individuals to limited GDP growth (Badgett 2014). The argument advanced by the Bank was that exclusion prevents LGBTI subjects from reaching their potential in education, in society and in the workforce. This has implications for social services, and prevents LGBTI citizens from fully contributing economically to their state and society. To fully 'develop', states must decriminalise and enact equality legislation. Queer economic participation becomes a sign of progress.

In this way the Bank's authority to regulate sexuality and gender identity was reinforced-and with it, the larger international (grand) narrative of LGBTI progress. This grand narrative operates through at least two temporal dynamics. The first is an obscuring of colonial histories, the Bank's previous engagements with

\footnotetext{
3 A copy of the letter can be found at https://www.hrw.org/news/2014/09/23/joint-cso-letter-world-bankdiscrimination-ugandas-health-sector. Accessed 27 November 2017.
} 
SOGI and its patchy record of rights. This obscuring of the past allows for a second dynamic - the creation of a future that ascribes to a progressive civilisational narrative of economically engaged queers as full participants within (and markers of) forward-looking statehood. These temporal movements allowed the Bank to operationalise a kind of habitual repetition of international law in a way that repeated problematic colonial forms of control.

\section{The Habitual Repetition of Empire}

Although the withdrawal of the loan represents a much stronger engagement with LGBTI rights on the part of an IFI than had previously been found, I argue that the World Bank's actions in the wake of the AHA were actually a reproduction of a well-established civilised/uncivilised dynamic-a form of habitual repetition of international law. This is because while the Bank might be new to issues of LGBTI rights, the technologies through which it engaged with the AHA are highly recognisable. At play is the 'civilising mission' that places the colonial and the colonised (represented by the Bank and Uganda) in dialectical opposition, allowing for the management of the unruly, homophobic and uncivilised 'developing world'. Yet, while the political rhetoric surrounding narratives of civilisation, sovereignty and African values were clearly expressed in Uganda, within the Bank, and in wider international legal structures, this civilisational dynamic is disguised. As Anghie (2007, p. 243) argues:

Colonialism reconstructed itself through new techniques...even while reproducing the fundamental structure of the civilizing mission... Further, it has created an international law which, even when it innovates, follows the familiar pattern of the colonial encounter, the division between civilized and uncivilized, the developed and the developing, a division that international law seeks to define and maintain using extraordinarily flexible and continuously new techniques.

Anghie's dichotomisation of the civilised and uncivilised as a technique for managing the Global South can be placed in conjunction with Lefebre's analysis of the particular in law in order to illuminate the Bank's actions and offer some insights into the role of temporality in international law. Lefebvre discusses the particular in relation to Deleuze's critique that 'law represents singular things as particulars' (Lefebvre 2008, p. 66). Or,

The particular is what a singular thing looks like, or what a singular thing is converted into, when put under a law. Defined by the criteria a law designates, a particular stands in for an indefinite number of equivalent, substitutable subjects. In short, a subject is transformed into a particular exemplification of a general law and is put into relating with other particulars (which also exemplify laws). (Ibid., p. 67) 
Uganda has its own historical, political and legal specificities, which play out in relation to SOGI. Yet the World Bank's response seemed deaf to this nuance, and instead cancelled a loan that was intended for a programme that was only tangentially relevant to LGBT criminalisation, justifying its actions through reference to harmful economic discrimination. In the context of the Bank, the linkages between economic discrimination and LGBTI rights have clear analytical and legal force. However, in Uganda the application of such frameworks is less clear: as activists have argued, it is difficult to identify or argue for the economic effects of homophobia or the relationship between discrimination and GDP in contexts in which poverty has multiple, widespread and intersecting causes. ${ }^{4}$ This is doubly the case in states such as Uganda in which there is already a 'profound anxiety' about economic uncertainty and the role that financial reward might play in encouraging participation in 'immoral activities' (Sadgrove et al. 2012, p. 116).

The World Bank's actions are, therefore, only really comprehensible at their most general or abstracted level, motivated by the clash between the civilised and uncivilised or the developed and the yet to develop. Ugandan LGBTI subjects are recognised as particular exemplifications of marginalised Global Southern subjects that must be aided through the mechanisms that the Bank has traditionally brought to bear-which includes financial conditionalities attached to legal and political changes. The specificities of the Ugandan situation-or indeed the danger of making a loan intended to support maternal healthcare conditional upon the protection of LGBTI rights-is not perceived as relevant.

It is in this regard that the World Bank's actions in Uganda are a kind of habitual repetition. This is particularly problematic when we consider Lefebvre's argument that although habitual repetition is often necessary, its danger lies in the potential for the confusion of judgment (the actualisation of the past in relation to perception and recollection) with the subsuming of the particular under a general set of rules (Lefebvre 2008, pp. 49, 67). This appears to be a trend that is evident in the discussion above: habitual repetition of colonial patterns of behaviour are reinforced by transnational and international actors based upon pre-figured assumptions and images. General rules for managing sovereignty, injustice or patterns of belonging are engaged, without paying sufficient attention to the specifics of a state's historical, cultural and material circumstances. At its most extreme, a queer actor has "no other existence or meaning besides the one given to it by law' (Lefebvre 2008, p. 67).

Here then, the World Bank, as a transnational body, renders complex and conflicting temporal-legal narratives as a singular trajectory of development, economic progress and good governance. The withdrawal of the loan contributes to an ongoing form of inattentive-or even subsumptive-judgment, creating global narratives of progress along singular teleologies of LGBTI rights. These global narratives require

\footnotetext{
${ }^{4}$ See the discussions that arose at the International Symposium, 'Sexuality and social justice: What's law got to do with it?' that took place in Brighton in 2015-https://www.ids.ac.uk/publication/sexualityand-social-justice-what-s-law-got-to-do-with-it-international-symposium-workshop-report. Accessed 24 November 2017.
} 
the translation and regulation of different forms of sexual and gender expression into habitual, recognisable patterns: patterns of rights-bearing subjects and economic actors. Any contradictions or elements of LGBTI belonging that trouble this narrative are smoothed over. This gives us a very teleological vision of progress, in which certain international and legal bodies seek to striate and dictate the future, locking us into a specific, pre-ordained path.

Multiple vectors of legal and non-legal control thus operate such that the complex dynamics that shape knowledge and temporalities intersect with law in a way that allows for LGBTI rights to be deployed as a language of governance (Sokhi-Bulley 2011). Rights become 'a central tool for establishing the truth claims of modernity' (Kapur 2014, p. 27); they are a good and valuable goal towards which we must always work. This justifies overt actions—-such as the loan's withdrawal—which draw upon and reinforce a set of indicators which are predicated on temporal (and colonial) histories and legitimised through international legal regimes.

One conclusion that can be drawn from this is that the question of how and who is able to perceive, frame and represent identities, temporalities, problems, and even sources of law, is vital. The ability to recognise and frame a problem (rather than simply finding solutions to problems that are assumed already to exist) constitutes a significant form of control because 'the problem always has the solution that it deserves, in terms of the way in which it is stated' (Deleuze 1991, p. 16; see also Deleuze 2011, p. 201). The clear danger is that the virtual, multiplicitous element of any problem or situation - that which allows for new and creative combinationsis 'dismembered' according to common sense, authority or doxa (Deleuze 2011, p. 195). In this way, we are limited by a habitual, pre-determined set of questions and responses with no possibility of new connections or more radical solutions. The danger is one of binding illusions or representations:

This is the dark thought I have had about representation for so long: we are immersed in it and it has become inseparable from our condition. It has created a world, a cosmos even, of false problems such that we have lost our true freedom: that of invention. (Olkowski 1999, p. 91)

We see this immersion in law's claims to universality. We are immersed in a cosmos of false problems and presented with ready-made categories of thought, history and law that offer us solutions. We might interpret Olkowski's warning as a warning against the particular claiming the status of the universal in order to project its own 'solution' or image across multiple legal and temporal terrains in a restrictive and closed operation of habit memory. Indeed this scenario captures quite well what appears to have occurred at the World Bank. In this case, factors at play included, but were not limited to, increased LGBTI visibility; international and state actors who operationalised sexuality and gender for their own (positive and negative) purposes; and the changing cultural, legal and community structures in Uganda and elsewhere. These complex dynamics were reduced to a question of economic exclusion, framed by economic indicators of development. In the sections that follow, I explore whether other framings are possible and what this might mean in the wider context of international LGBTI rights. 


\section{Framing New Problems: Encountering the Past and Attentive Judgment}

The argument thus far has been that the international legal system contributes to problematic forms of disciplinary control of sexual orientation and gender identity across international topologies through the habitual repetition of historical patterns of colonial control. This leaves open the question of whether this repetition could have been avoided by the Bank, but also whether this critical stance can illuminate how we might better imagine a 'queer' international human rights law.

Given the limitations of habitual repetition embodied in the World Bank's response to the AHA, it is clear that an alternative approach is necessary. Lefebvre suggests that in a small minority of cases, it is possible to identify a moment of uncertainty to which previous, habitual rules cannot easily attach. What occurs here is a pause in which we fail to unconsciously and immediately act out the habitual pattern of the past or the predictable future (Al-Saji 2004). This pause begins with a failure of recognition and the suspension of spontaneous linkages between perceptions and recollections. It demands that attention is paid to the singularity at hand, and as such, it reveals the virtual past as the condition and element of judgment. We are faced with the need to leap into the virtual past at its more distant extensions and to experiment with recollections in order to respond to the situation faced (Lefebvre 2008 , p. 182). What is required is a creative re-working of memory; the opening up of the unthought-of and unsaid in response to the new (Braidotti 2006, p. 173). This is attentive judgment, or the active actualisation of memory. In the legal context, this attentive judgment is the becoming of law-its reinvention and re-folding as it responds to external events, but also reconfigures itself with respect to past and future (Mawani 2015, p. 260). This second, attentive judgment opens up much more unpredictable dimensions of past, present and future. Here we have a history that 'defies repeatability or generalisation'; a present directed towards change and 'the potentiality of the future to be otherwise than the present' (Grosz 2000, p. 230).

To translate this into the framework of international law: the repetition of the past does not have to be habitual-the repetition of colonial memory can (and should) be halted. In the actions of the World Bank, the meaning given to Ugandan queers is that they are economically excluded subjects deprived of rights. Within Uganda, the dominant narrative was almost exactly the reverse of thisa rejection of international norms and a reassertion of national identity through the symbolic exclusion of the homosexual other. Both sets of perceptions rested upon a framework of civilisational clash. Yet even a brief overview of the political rhetoric and legal judgments surrounding the AHA suggests that multiple other meanings were potentially present. Ugandan queers are de-sexualised subjects in the David Kato Kisuule judgment, or they are economically vulnerable individuals lured into 'immoral behaviour', or they are rights-bearing individuals and communities - although with the parameters of rights protections still to be decided. In this sense, queer actors, or queer bodies seem to be positioned-or stretched-across multiple spatial, temporal and legal domains, which compete over the way in which they are perceived and recognised. Through this management, certain dominant spatio-legal histories are emphasised over others. 
Given this polyphony of queer positionings in law, it is possible to trace how the loan's cancellation might have been otherwise framed, even within the restrictive framework of the Bank. The AHA was perceived as an attack on vulnerable Ugandan queer minorities who, as economically excluded subjects, were prevented from reaching their full developmental potential, resulting in the imposition of punitive financial penalties or conditionalities. Actualised here is a grand narrative of civilisational management in which the Global South must be regulated and brought to development. But when examined in detail, the singularity of the Ugandan situation resists its assimilation as a particular exemplification of a general rule. The loan itself was, at best, only tangentially linked to issues of LGBTI discrimination. In this sense, its withdrawal only makes sense-only has meaning-when understood through the civilising mission. If we remove or resist this framing, or if we encounter the loan as a singularity, the World Bank's actions become increasingly unjustifiable.

In the first instance, then, this is not an argument that the loan should not have been withdrawn. It is an argument that the justification for the loan's withdrawal should not have been subsumed under general or abstract rules of the civilisational binary or linked to LGBTI rights. At the very least, the loan should have been encountered as a singularity rather than an expression of colonial managementanimated by a consideration of healthcare, maternal mortality, and approaches to healthcare funding within the Bank and in Uganda. This is not to say that questions of healthcare cannot intersect with issues of sexuality, sexual orientation, sex characteristics or gender identity, but that the overwhelming grand narrative of LGBTI rights management prevented their singular perception and instead reinscribed problematic civilisational dichotomies.

Nor is this an argument that it is always inappropriate to address questions of SOGI justice in relation to healthcare or economic exclusion. But in this situation these framings were largely unhelpful. Drawing upon Duval's (2013) insistence upon agnosticism in our selection of sources of law, it is possible to identify how the Bank's actions were an attempt to perpetuate a set of legal norms and legal changes. And while we might argue that progress on SOGI justice is a good and valuable goal, the Bank pursued SOGI justice in a way that was abstracted from the specific dynamics of legal change in Uganda-which had thus far devolved upon an incremental approach supported by the careful avoidance of civilisational binaries. Thus, the Bank's actions in Uganda reinscribe a framework where Ugandan queers are misperceived as economically excluded subjects and within which LGBTI rights can be denied or dismissed through rhetorics of cultural specificity and anti-imperialism.

However, the Bank was clearly pushing at the edges of its mandate and expanding the reach of its legal and political power in its turn to LGBTI rights. And at this edge, its actions remained potentially ineffective and dangerous. This raises a much larger question of whether current approaches to LGBTI rights are similarly exhausted. Certainly a simple reframing of the World Bank loan or of questions of sexual orientation and gender identity in Uganda does not speak to larger problems of colonising patterns or unequal power relations in international law and international human rights law. Moreover, it does not address structural forces in institutions like the Bank that inhibit the more radical potential of arguments for rights or 
SOGI justice (Anghie 2007; Bedford 2009). The larger issue at play here is therefore one of structural factors that perpetuate (or at least do not prevent the perpetuation of) a civilisational binary. The ongoing existence of this binary maintains the now well-established parameters through which arguments for and against SOGI justice are articulated and restricts our capacity to imagine new futures. It is to this question of how queer futures might be differently imagined in international law that the final section of the paper turns.

\section{Imagining New Futures: Queering International Law?}

The problem demonstrated above is one of international legal assemblages of LGBTI rights that are trapped in patterns of civilisational management, from which there is an urgent need to escape. Returning to the theoretical frames deployed throughout this paper, the 'problem' is central to Lefebvre's analysis of judgment: a 'legal concept is not applied to an independent state of affairs but is formed from within a situation whose facts are established by being taken up in the context of a jurisprudential problem' (Lefebvre 2008, p. 216). Legal concepts are actualised in response to a perceived legal problem, and the way in which the problem is posed creates the parameters for the actualisation of a legal concept. In attentive judgment, the pure past of law is actualised in such a way as to create new linkages, resulting in new assemblages and new legal concepts. For Lefebvre then, attentive judgment speaks to the singular and the creative in law. Law here is not the application of abstract rules, but the act of encounter, perception, problem creation and the actualisation of the new. It is this which is missing from international responses to the AHA thus far. The linkages brought to bear are consistently those which repeat but obscure a foundational civilisational binary.

This argument can be brought into resonance, if not synthesis, with Anghie's observations on the operation of international law. Anghie (2007, p. 311) argues that international law

lacks the conceptual apparatus to interrogate fundamental characteristics of the colonial encounter, the construction of the non-European society as primitive, violent, uncivilized and therefore non-sovereign. Sovereignty is formulated in such a way as to exclude the non-European; following which, sovereignty can then be deployed to identify, locate, sanction and transform the uncivilized.

Taking these two positions together, the encounter between formerly colonial and formerly colonised states is always already mediated by a set of ready-made problems and concepts that have grown from the civilising mission of the colonial encounter. This leads to scenarios in which, even at the supposed 'cutting edge' of LGBTI rights developments, the habitual recognition of old patterns continues. The virtual past of international law is habitually actualised as a particular exemplification of colonial regulation predicated upon the dichotomisation of the civilised and the uncivilised.

The challenge, posed by Anghie and Lefebvre in very different vocabularies, is whether there is the potential for creativity in international law-whether attentive 
judgment can occur. This potentiality is not assured: past attempts to use international law - and particularly human rights - in the interests of the Global South have been at best sporadically successful, as the more creative aspects of rights are enfolded into existing regimes of power (Anghie 2007). And, as I have argued here, even the most 'experimental' attempts at SOGI justice on the part of the Bank, fall back into a civilisational dichotomy. Genuine experimentation in this instance therefore demands a creative leap into the virtual past in a way that undermines this dichotomy. It requires, in Deleuzian terms, an encounter (Deleuze 2011, p. 176). The encounter of law and problematic queer bodies can constitute that which 'forces us to think' (Deleuze 2011, p. 139) — the moment of 'ethical weight' (Halsey 2008) when conceived structures are found wanting, and when the language we have for addressing the future is not capable of doing so- the time of the 'untimely' (Deleuze and Guattari 2009, p. 111).

This perhaps offers a glimpse of what Lefebvre (2009) calls 'the growth and becoming of law' that operates in the singular encounter between international law and the unknown, queer or unrecognisable. In the discussion above, conceived structures were insufficient - they remained trapped within a dogmatic image of law and rights that was tied to a civilisational binary. A creative or attentive repetition of international law with respect to LGBTI rights might be one which dived into and repeated the virtual past in ways that explode this binary.

Some care is required here. The point is not to deny Anghie's argument that civilisational binaries or the colonial encounter have operated as a foundational, habitually repeated grand narrative in international law. It is instead to call for ways of framing future international action in a way that subverts the role of this binary as an ever present but unacknowledged grand narrative. In this regard, Deleuze's (2011) argument that the dialectic is composed of more than just negative oppositions is of some use. Deleuze argues that the dialectic must be understood as the play of difference: '[r]evolution never proceeds by way of the negative...the negative is both a shadow of the problem and false problem par excellence. Practical struggle never proceeds by way of the negative, but by way of difference and its power of affirmation' (Deleuze 2011, p. 259). Reynolds (2007) suggests that Deleuze's position might best be understood as one that seeks a 'dialectic of the multiplicities of difference'. Thus we might use Deleuze to argue that the civilisational binary traps us within a negative and dogmatic dialectic. The point for Deleuze is to re-cast the dialectic as the constant movement between the virtual and the actual, rather than remaining stuck within stable, restrictive and negative regimes of identity-based oppositions. Virtual memory, or the 'play of difference' is always more than our current combinations and understandings of history, community and law, but it can only be known through its singular actualisation (Deleuze 2011, p. 257). The challenge is to pay attention to the jarring nature of the encounter and 'counteractualise' the virtual past in new forms in response to this. In short, we should not deny the truth or ongoing force of civilised/uncivilised binaries in international law, but we should seek to actualise the virtual past of law in new forms that actively subvert and refuse this framework.

The point here, therefore, is that there is not one single or 'best' answer to what a queer international human rights law might look like. Instead, this is a 
perspective that calls for openness to experimentation, to encounters and to framings that in Anghie's (2007, p. 319) terms, 'undermine the dichotomy between colonizer and colonized, self and other on which the civilizing mission is based'. This experimentation could take many forms, and there are various examples of creative uses of law in relation to SOGI issues. For example in $S M U G v$ Lively, Ugandan LGBTI groups used the US Alien Tort Statute to sue the evangelical Pastor Scott Lively in the US courts for his role in stoking homophobic discourses around the time of the drafting of the AHB. As with the World Bank loan, this case could be characterised as a transnational response to the effects of the AHA, but it was one in which Ugandan activists played a much more central role. It perceived and actualised a different set of facts and rules to those found in the cancellation of the loan, dealing directly with religion, freedom of expression, information and disinformation around questions of sexual orientation and gender identity. It was also a case in which transnational dynamics of SOGI and colonial histories were exposed and conceptualised as a present problem rather than a historical fact.

It is not necessarily surprising that examples of creative approaches to SOGI can be found in the actions of those who have historically been powerless or denied agency within international systems of law and politics-those 'stretched bodies' described above. Nor is it surprising to see the multiplicity of tactics adopted by Ugandan activists - from incremental approaches at home, to much bolder challenges abroad. There is a danger in extrapolating the actions of Ugandan activists into a general set of rules, but we can at least identify a set of critical parameters with which we might engage. We can, for example, pay closer attention to the experiences of those who exist within and across the contradictions of international legal systems, not as sources of data, nor as bodies to be managed, but as leaders and as generators of creative strategies for change. We can centralise questions of why queerness is engaged within singular situations or incidents, how it is symbolically linked to larger issues, and the vocabularies through which these interlinkages are expressed. And, in the encounter between queerness and international law we can be continuously mindful of what concepts are actualised, what sources of law are used and what is perceived as legally relevant or not relevant in any given scenario.

Thus the queer potential in international law does not necessarily emerge from the growing suite of transnational norms and protections pertinent to LGBTI rights but in the sense used by Colebrook, when she suggests that queerness is the point at which the production of the normal is exposed and is therefore presented as contingent and subject to change (Colebrook 2009). By looking closely at one particular event - the World Bank's cancellation of a loan-we can expose the grand narratives that are continuously repeated and denied in the operation of international law. Law striates and divides time and space, but always fails to capture the fullness of queer experience. Universal claims of law, rights or development are challenged by the movement and chaos of multiple queer histories, temporalities and embodiments. These encounters expose the universalising myths of the pluriversal international system and demand acknowledgment of the fractured multiplicity that exists within. 


\section{Conclusion}

In examining in depth just one event in the recent history of international LGBTI rights - the World Bank's response to the AHA - it is possible to explore and expose the multiple and contradictory histories that this single instance contains. In withdrawing the loan and linking this withdrawal directly to the AHA, the World Bank engaged in a form of habitual or inattentive recognition. It failed to challenge grand narratives of colonial encounter or the civilisational binaries that underpin these grand narratives. This is particularly problematic because within Uganda, language that tapped into anti-colonial, anti-imperial and anti-LGBTI rights sentiment carried significant force. This allows for the ongoing co-option of anti-LGBTI sentiment into wider nationalistic political projects. More simply, in responding to the immediate 'problem' of the AHA in a habitual fashion, the Bank failed to perceive more deeply rooted historical and structural questions of rights, colonial memory and SOGI justice.

Ironically, a great deal of legal and temporal work was required to facilitate this habitual repetition - the Bank was, in some senses, working at the edges of its powers. This demonstrates the extent to which the 'problem' of SOGI justice here is not only legal or policy based, but theoretical and historical. There is an ongoing need for new conceptual framings through which arguments for SOGI justice can be formulated. Thus, queering international law is achieved not simply (or not only) through the habitual repetition of already existing LGBTI human rights protections. Instead, there is a need to take seriously the conflicts and messy contradictions of LGBTI rights and SOGI justice as they occur and are embodied in singular locations. Encountering these contradictions as singularities and refusing to fall back unthinkingly into the habitual repetition of already existing languages of LGBTI rights protections is the first step in a creative approach to SOGI justice.

Thus, with Anghie (2007, p. 320), we might argue that 'there is no substitute for continuously questioning developments in international law on the basis of a vision of international justice that is informed by an understanding of the colonial history of international law and its enduring effects'. The challenge is to re-animate old problems by actualising the past in new ways. It is here, through a postcolonial reading of Deleuzian jurisprudence and a Deleuzian method for framing a postcolonial problem, that we might encounter the true-or at least the more challenging'cutting edge' of queer international human rights law.

Acknowledgements This work was funded by The Leverhulme Trust through a Leverhulme Early Career Fellowship grant. Many thanks to Professor Mark James, to Jens Theilen, to Dr Christian Klesse and to two anonymous reviewers for their comments on earlier versions of this paper.

Open Access This article is distributed under the terms of the Creative Commons Attribution 4.0 International License (http://creativecommons.org/licenses/by/4.0/), which permits unrestricted use, distribution, and reproduction in any medium, provided you give appropriate credit to the original author(s) and the source, provide a link to the Creative Commons license, and indicate if changes were made. 


\section{References}

Al-Saji, Alia. 2004. The memory of another past: Bergson, Deleuze and a new theory of time. Continental Philosophy Review 37(2): 203-239.

Alston, Philip 2014. The two words that scare the World Bank. The Washington Post. https://www. washingtonpost.com/opinions/philip-alston-the-world-bank-treats-human-rights-as-unmentiona ble/2014/11/07/9091dafa-65da-11e4-9fdc-d43b053ecb4d_story.html?utm_term=.8892de84622e. Accessed 20 March 2018.

Anghie, Antony. 2002. Colonialism and the birth of international institutions: Sovereignty, economy, and the mandate system of the League of Nations. New York University Journal of International Law and Politics 34: 513-634.

Anghie, Antony. 2006. The evolution of international law: Colonial and postcolonial realities. Third World Quarterly 27(5): 739-753.

Anghie, Antony. 2007. Imperialism, sovereignty and the making of international law. Cambridge: Cambridge University Press.

Anghie, Antony. 2013. Whose utopia? Human rights, development, and the Third World. Qui Parle: Critical Humanities and Social Sciences 22(1): 63-80.

Badgett, M.V. 2014. The economic cost of stigma and the exclusion of LGBT people: A case study of India. Washington, DC: World Bank.

Bedford, Kate. 2009. Developing partnerships: Gender, sexuality and the World Bank. Minneapolis: University of Minnesota.

Braidotti, Rosi. 2006. Transpositions. Cambridge: Polity.

Brodnig, Gernot. 2002. The World Bank and human rights: Mission impossible? Praxis: The Fletcher Journal of Development Studies 17: 1-15.

Colebrook, Claire. 2009. On the very possibility of queer theory. In Deleuze and queer theory, ed. Chrysanthi Nigianni, and Merl Storr. Edinburgh: Edinburgh University Press.

Darrow, Mac. 2006. Between light and shadow: The World Bank, the International Monetary Fund and International Human Rights Law. Oxford: Hart.

de Camargo Jr., Kenneth, and Reuben Mattos. 2007. Looking for sex in all the wrong places: The silencing of sexuality in the World Bank's public discourse. In SexPolitics: Reports from the front lines, ed. Richard Parker, Rosalind Petchesky, and Robert Sember. Rio de Janeiro: Sexuality Policy Watch.

de Vos, Pierre. 2001. A bridge too far? History as context in the interpretation of the South African Constitution. South African Journal of Human Rights 17(1): 1-33.

Deleuze, Gilles. 1991. Bergsonism (trans: Hugh Tomlinson, and Barbara Habberjam). New York: Zone Books.

Deleuze, Gilles. 1996. On human rights. L’Abécédaire de Gilles Deleuze, avec Claire Parnet. http://www. generation-online.org/p/fpdeleuze10.htm. Accessed 8 April 2014.

Deleuze, Gilles. 2011. Difference and repetition (trans: P. Patton). London: Continuum.

Deleuze, Gilles, and Felix Guattari. 2009. What is philosophy? (trans: Graham Burchell, and Hugh Tomlinson). London: Verso.

Duval, Antoine. 2013. Lex sportiva: A playground for transnational law. European Law Journal 19(6): $822-842$.

Feder, J. Lester. 2014. World Bank delays $\$ 90$ million loan to Uganda as Bank President blasts anti-gay laws. Buzzfeed. https://www.buzzfeed.com/lesterfeder/world-bank-delays-90-million-loan-to-ugand a-as-bank-presiden?utm_term=.ktzPz6j3z\#.syYYb7Pjb. Accessed 4 August 2016.

Fujita, Sanae. 2011. The challenges of mainstreaming human rights in the World Bank. International Journal of Human Rights 15(3): 374-396.

Gosine, Andil. 2010. The World Bank's GLOBE: Queers in/queering development. In Development, sexual rights and global governance, ed. Amy Lind. London: Routledge.

Greenhouse, Carol J. 1989. Just in time: Temporality and the cultural legitimation of law. The Yale Law Journal 98(8): 1631-1651.

Grosz, Elizabeth. 2000. Deleuze's Bergson: Duration, the virtual and a politics of the future. In Deleuze and feminist theory, ed. Claire Colebrook, and Ian Buchanan. Edinburgh: Edinburgh University Press.

Gupta, Alok. 2008. This alien legacy: The origins of 'sodomy' laws in British colonialism. New York: Human Rights Watch.

Halsey, Mark. 2008. Deleuze and Deliverance: Body, wildness, ethics. In Deleuze/Guattari and ecology, ed. B. Herzogenrath. London: Palgrave Macmillan. 
Jjuuko, Adrian. 2013. The incremental approach: Uganda's struggle for the decriminalisation of homosexuality. In Human rights, sexual orientation and gender identity in The Commonwealth: Struggles for decriminalisation, ed. Corinne Lennox, and Matthew Waites. London: Institute of Commonwealth Studies.

Jjuuko, Adrian. 2016. International solidarity and its role in the fight against Uganda's anti-homosexuality bill. In Gender, sexuality and social justice: What's law got to do with it?, ed. Kay Lalor, Elizabeth Mills, Arturo Sánchez García, and Polly Haste. Falmer, Sussex: Institute of Development Studies.

Kaoma, Kapya. 2012. Colonizing African values: How the US Christian Right is transforming sexual politics in Africa. Somerville, MA: Political Research Associates.

Kapur, Ratna. 2014. In the aftermath of critique we are not in epistemic free fall: Human rights, the subaltern subject, and non-liberal search for freedom and happiness. Law and Critique 25(1): 25-45.

Kim, Jim Yong. 2014. World Bank Group President Jim Yong Kim: Discrimination by law carries a high price, World Bank. http://www.worldbank.org/en/news/opinion/2014/02/28/world-bank-group-presi dent-jim-yong-kim-discrimination-law-price. Accessed 29 March 2017.

Lefebvre, Alexandre. 2008. The image of law: Deleuze, Bergson, Spinoza. Stanford: Stanford University Press.

Lefebvre, Alexandre. 2009. The time of law: Evolution in Holmes and Bergson. In Deleuze and law: Forensic futures, ed. Rosi Braidotti, Claire Colebrook, and Patrick Hanafin. Basingstoke: Palgrave Macmillan.

Mawani, Renisa. 2015. The times of law. Law and Social Inquiry 40(1): 253-263.

McClintock, Anne. 1995. Imperial leather: Race, gender and sexuality in the colonial contest. London: Routledge.

Menashy, Francine. 2013. Interrogating an omission: The absence of a rights-based approach to education in World Bank policy discourse. Discourse: Studies in the Cultural Politics of Education 34(5): 749-764.

Nyanzi, Stella. 2014. Queer pride and protest: A reading of the bodies at Uganda's first Gay Beach Pride. Signs: Journal of Women in Culture and Society 40(1): 36-40.

Nyanzi, Stella, and Andrew Karamagi. 2015. The social-political dynamics of the anti-homosexuality legislation in Uganda. Agenda 29(1): 24-38.

Olkowski, Dorothea. 1999. Gilles Deleuze and the ruin of representation. Berkeley: University of California Press.

Oloka-Onyango and 9 Others v. Attorney General [2014] UGCC 14, Constitutional Petition No. 8 of 2014 Uganda, Constitutional Court.

Oloka-Onyango, Joe. 2015. Debating love, human rights and identity politics in East Africa: The case of Uganda and Kenya. African Human Rights Law Journal 15(1): 28-57.

Palacio, Ana. 2006. The way forward: Human rights and the World Bank. In The world bank: Law, justice and development. http://siteresources.worldbank.org/EXTSITETOOLS/Resources/PalacioDevtOutr each.pdf. Accessed 27 February 2018.

Rao, Rahul. 2014. The locations of homophobia. London Review of International Law 2(2): 169-199.

Reynolds, Jack. 2007. Wounds and scars: Deleuze on the time of the event. Deleuze Studies 1(2): $144-166$.

Sadgrove, Joanna, Robert M Vanderbeck, Johan Andersson, Gill Valentine, and Kevin Ward. 2012. Morality plays and money matters: towards a situated understanding of the politics of homosexuality in Uganda. The Journal of Modern African Studies 50(1): 103-129.

Sexual Minorities Uganda $v$ Scott Lively Civil Action 3:12-CV-30051 (MAP) (US District Court for the District of Massachusetts).

Sokhi-Bulley, Bal. 2011. Government(ality) by experts: Human rights as governance. Law and Critique 22(3): 251

Uberoi, Patricia. 1996. Social reform, sexuality and the state. New Dehli: Sage.

Wahab, Amar. 2016. Homosexuality/homophobia is un-African? Un-mapping transnational discourses in the context of Uganda's Anti-Homosexuality Bill/Act. Journal of Homosexuality 63(5): 685-718.

Williams, James. 2003. Gilles Deleuze's difference and repetition: A critical introduction and guide. Edinburgh: Edinburgh University Press.

Williams, James. 2011. Gilles Deleuze's philosophy of time: A critical introduction and guide. Edinburgh: Edinburgh University Press. 